\title{
Project structure blamed for Beagle 2 loss
}

Laura Nelson, London

For the European Space Agency (ESA) and the British government, the Beagle 2 Mars lander was a bold experiment in the delegation of project management to the people building the probe.

But according to an official inquiry, this experiment was an expensive failure and should not

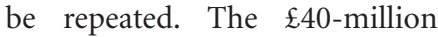
(US\$72-million) probe was lost as it attempted to land on Mars on Christmas Day last year. Future projects, the inquiry says, should be far more rigorously controlled and documented.

The panel's summarized findings were released on 24 May and swiftly accepted by ESA. "The creative approach used with Beagle 2 was probably a step too far," admits David Southwood, the space agency's chief scientist. "Maybe I should have never let it go."

Beagle 2 was an adjunct to Mars Express, its mother craft, and ESA allowed its British design team, led by Colin Pillinger, a planetary scientist at the Open University, Milton Keynes, considerable autonomy in managing the project. The lander hitched a ride with Mars Express when it left Earth last June. When it reached Mars' orbit on 19 December, Beagle 2 was successfully ejected, but was never heard from again.

ESA contributed $£ 20$ million to the probe's costs and most of the rest came from the UK government. Additional funding came from EADS-Astrium - a Stevenagebased company that built some of the lander's components - the Open University and the National Space Centre in Leicester.

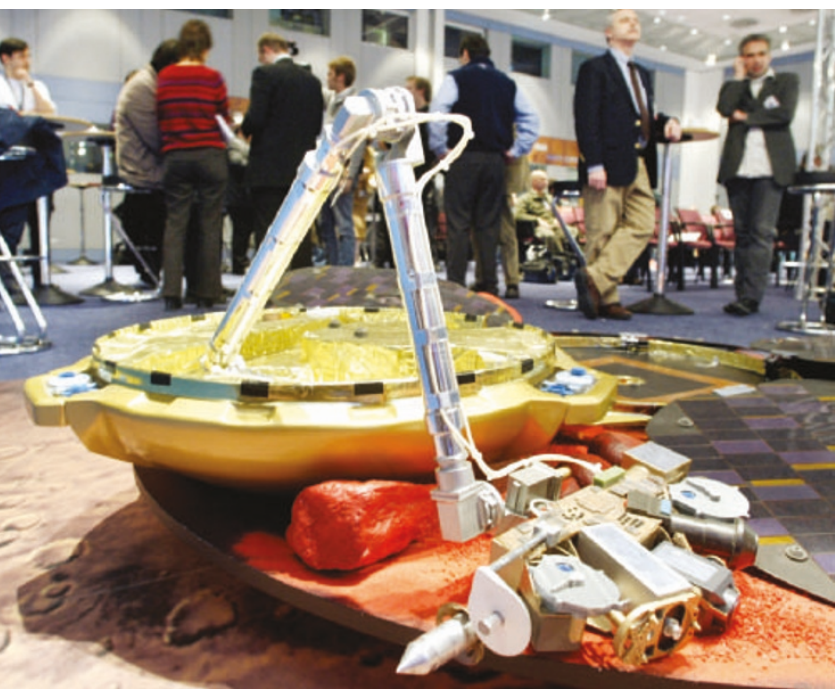

managed directly by the agency, and subject to its normal planning and costing procedures.

The other findings highlight specific shortcomings in the testing and cost-accounting of the Beagle 2 mission. They say that future probes should have more robust telemetry and communications systems, should be rigorously tested for resistance to shock, and designed so that hatches and other detachable parts are less likely to collide with the main body if they fall off.

The panel also recommends far more rigorous testing of the parachute system, which some experts have identified as the most likely cause of Beagle 2's failure. But the inquiry reached

The inquiry panel, which was chaired by ESA inspector-general, René Bonnefoy, and David Link, a former director of EADSAstrium, argues forcefully that ESA should have treated Beagle 2 as an integral part of Mars Express.

The full report is not being made public, apparently to protect the confidentiality of submissions from ESA member governments and from private companies. But the panel released a list of 19 recommendations, which have been accepted by Southwood and by the British science minister, David Sainsbury.

About half of the recommendations concern the unprecedented level of autonomy that the project enjoyed from ESA's normal management structures. The panel roundly condemns this approach, and calls for future projects "which are critical to overall mission success or have a very high public profile" to be no firm conclusion on what became of the missing probe.

Accepting the findings at a press conference in London, Sainsbury said: "We must apply to the instrument the same kind of rigour and controls that are applied to the main spacecraft."

And Southwood accepted some personal responsibility for the craft's loss. "I was irresponsible not to have taken responsibility," he told Nature. He added that the probe's management structure had lacked accountability. "You've got to know who is giving orders to whom."

Pillinger said that the project team had done as well as it could. "We did our best, and that's all we could do," he said. "What I'm interested in is looking to the future," he added, urging ESA to make the earliest possible decision to return to Mars again.

\section{Monsanto wins seven-year court battle for seed patent}

\section{David Spurgeon, Montreal}

In a major boost for agricultural biotechnology, Canada's supreme court has ruled that a patent on a genetically modified seed extends to the cells and genes in the resulting plant.

The 21 May ruling is the last word in a seven-year battle between biotech firm Monsanto, based in St Louis, Missouri, and Saskatchewan farmer Percy Schmeiser.

Monsanto brought the action because its transgenic canola was found growing in Schmeiser's fields when he did not have a licence from the firm to cultivate the crop. Schmeiser, who maintains that the canola seeds blew on to his property, was ruled to have infringed Monsanto's patent by growing the plants without a licence. The gene in question renders canola resistant to Monsanto's Roundup weed-killer.

The ruling, said to be the first of its type in any country, thrilled the biotech industry and angered consumer, environmental and farmers' groups. In a statement, Monsanto said that the ruling set "a world standard in intellectual property protection".

The case was seen as critical for the agricultural biotechnology industry, which holds thousands of patents likely to be affected by it and has many more pending. But critics say that the decision will give the industry too much control over farmers.

"This decision does not just condemn Percy Schmeiser, it also condemns the broader community," says Andrea Peart, director of health and environment with the environmental group Sierra Club of Canada. "The responsibility of dealing with the environmental contamination by genetically engineered genes will now be shouldered by the public, not the polluter."

The ruling contrasts with the Supreme Court's 2000 decision on the Harvard Mouse, a transgenic rodent used in cancer research. It said that the mouse could not be patented in Canada, although courts in the United States and Europe have permitted patents. But the court found that the nature of commercial agriculture meant that plants grown from the seeds constituted a 'use' of the technology covered by the patent. 